\title{
Supervisi Akademik dan Bagaimana Kinerja Guru
}

\author{
Miftahul Laili Hasanah \\ IAIN Batusangkar \\ miftahullali95@gmail.com \\ Muhammad Kristiawan \\ Universitas Bengkulu \\ muhammadkristiawan@unib.ac.id
}

\begin{abstract}
This study aimed at investigating the implementation of academic supervision by principals, from the planning, implementation, and follow-up. Academic supervision gave impact on teachers' performance. Teachers' evaluations will be seen from the lesson plan, the implementation of instruction, assessment of learners and the follow-up. To achieve these objectives, we used quantitative approach. Data were collected through observation and questionnaires using Likert scale. The analysis used was simple regression analysis. The results showed there was significant correlation between the academic supervision by principals towards the teachers' performance. If the academic supervision increases, the teachers' performance will also increase.
\end{abstract}

Keywords: Academic Supervision, Teachers' Performance, Quality Output.

\begin{abstract}
Penelitian ini bertujuan untuk menyelidiki pelaksanaan supervisi akademik kepala sekolah, dari perencanaan, pelaksanaan, dan tindak lanjut. Supervisi akademik berdampak pada kinerja guru. Evaluasi guru akan dilihat dari rencana pembelajaran, pelaksanaan pembelajaran, penilaian peserta didik. dan tindak lanjut. Untuk mencapai tujuan ini, kami menggunakan pendekatan kuantitatif. Data dikumpulkan menggunakan observasi dan kuesioner menggunakan skala likert. Analisis yang digunakan adalah analisis regresi sederbana. Hasil penelitian menunjuke.kn bahwa ada bubungan yang signifikan antara supervisi akademike kepala sekolah terbadap kinerja guru. Jika supervisi akademik kepala sekolah naik maka kinerja guru juga akan meningkat.
\end{abstract}

Kata kunci : Pengawasan Akademik, Kinerja Guru, Output Kualitas.

\section{Pendahuluan}

Purbasari, (2015: 51) menyatakan bahwa pelaksanaan supervisi akademik dapat mempengaruhi peningkatan kinerja guru dalam kegiatan pembelajaran. Kemudian Irawadi juga menjelaskan bahwa kinerja guru Sekolah Dasar Negeri se-kecamatan Lintau Buo Utara sebesar $47.9 \%$ ditentukan oleh supervisi kunjungan kelas dan sisanya 52,1\% ditentukan oleh faktor lain. Apabila kegiatan supervisi kunjungan kelas dilaksanakan secara bekesinambungan oleh kepala sekolah terhadap guru yang dibina maka supervisi kunjungan kelas akan mampu meningkatkan kinerja guru menjadi lebih baik (Irawadi, 2013).

Selanjutnya hasil temuan Asna menunjukkan bahwa koofesien antara Pelaksanaan Supervisi Kepala TK (X1) dengan kinerja guru TK di Padang Panjang (y) berkolerasi positif dan signifikan yaitu sebesar 33,9\% dengan koofesien korelasi 0,583. Hal ini berarti derajat korelasi adalah kuat (Asna, 2013). Selanjutnya hasil penelitian yang dilakukan oleh Sarasasti menjelaskan bahwa usaha pengawas dan kepala sekolah dalam meningkatkan kineja guru PAI adalah dengan menjalankan tujuh program yang dilakukan oleh pengawas dan kepala sekolah dalam peningkatan kinerja guru madrasah kota Solok (Sarasasti, 2015). 
Penelitian Aslamiah juga menyatakan bahwa, terdapat hubungan antara pelaksanaan supervisi akademik kepala sekolah terhadap kinerja guru di MTsN Imadun Najah. Pelaksanaan supervisi akademik sangat penting dilakukan oleh kepala sekolah, karena salah satu faktor yang menjadikan sekolah baik dan berkualitas itu adalah sumber daya manusia yang ada di sekolah tersebut terutama guru (Aslamiah, 2011). Terakhir hasil penelitian Defrisiswardi menyatakan bahwa supervisi akademik kepala sekolah berkontribusi sebesar 19,2\% terhadap kompetensi pedagogik guru. Hal ini mengisyaratkan bahwa supervisi akademik kepala sekolah merupakan faktor yang sangat penting dan perlu diperhatikan dalam peningkatan kompetensi pedagogik guru (Defrisiswardi, 2013).

Kepala madrasah menurut Peraturan Menteri Pendidikan Nasional Nomor 13 tahun 2007, dalam aturan ini pemerintah memandang perlu adanya standar penentuan kualifikasi seseorang untuk dapat diangkat sebagai kepala sekolah atau madrasah. Sedangkan menurut Peraturan Pemerintah No 19 tahun 2005 pasal 56 menyatakan bahwa pemantauan dilakukan oleh pimpinan satuan pendidikan dan komite sekolah/ madrasah atau bentuk lain dari lembaga perwakilan pihak-pihak yang berkepentingan secara teratur dan berkesinambungan untuk menilai efisiensi, efektivitas, dan akuntabilitas satuan pendidikan dan pasal 57 menjelaskan bahwa supervisi yang meliputi supervisi manjerial dan akademik dilakukan secara teratur dan berkesinambungan oleh pengawas atau pemilik satuan pendidikan dan kepala satuan pendidikan. Dalam kaitannya dengan manajemen dan kepemimpinan kepala sekolah, supervisi lebih ditekankan pada pembinaan dan peningkatan kemampuan kinerja tenaga kependidikan di madrasah/ sekolah dalam melaksanakan tugas (Asmendri, 2012; Kristiawan dkk, 2019).

Berdasarkan observasi yang peneliti lakukan pada tanggal 2 sampai 7 Mei 2016, Madrasah Tsanawiyah Tabek jika dilihat dari kinerja gurunya sudah baik dan berbeda dari madrasah-madrasah lain yang peneliti temukan. Hal ini dibuktikan dengan kedisiplinan guru yang datang dan pulang tepat waktu, guruguru menyambut kedatangan siswa setiap paginya, di Madrasah Tsanawiyah Tabek menyediakan satu orang guru tahfiz Al-Qur'an dan di madrasah ini selalu rutin diadakan shalat Zuhur berjamaah di masjid Syura Tabek kecuali hari Jum'at dan sebelum shalat dimulai diadakan kultum yang diisi oleh siswa-siswi Madrasah Tsanawiyah Tabek.

Dalam hal ini peneliti membandingkan Madrasah Tsanawiyah Tabek dengan Madrasah Tsanawiyah Swasta Rambatan. Madrasah Tsanawiyah Swasta Rambatan jika dilihat dari kinerja gurunya, di mana guru-guru tidak pulang tepat waktu, yaitu yang pulang tepat waktu hanya guru-guru yang sudah sertifikasi saja, untuk menyambut kedatangan siswa hanya sebagian guru yang melakukan yaitu guru piket, mengenai guru tahfiz Qur'an MTsS Rambatan juga menyediakan satu 
orang guru tahfiz Qur'an, dan untuk pelaksanaan shalat Zuhur berjamaah hanya dilakukan oleh guru-guru saja di sekolah, hal ini terbukti dari hasil wawancara peneliti dengan kepala Madrasah Tsanawiyah Swasta Rambatan yang bernama ibu Nurlaili, S.Ag, M.Pd.I dan guru Aqidah Akhlak yang bernama ibu Fitri Yanti, S.Pd pada tanggal Kamis 13 Oktober 2016 di ruangan Kepala Madrasah Tsanawiyah Swasta Rambatan.

Dari beberapa keunggulan Madrasah Tsanawiyah Tabek seperti yang telah peneliti jelaskan diatas, maka dari itu peneliti tertarik unutk meneliti di Madrsah Tsanawiyah Tabek dan penelitian ini penting dilakukan untuk mengetahui pengaruh supervisi akademik yang dilakukan oleh kepala madrasah terhadap kinerja guru yang sudah baik tersebut atas dasar beberapa penelitian yang telah dilakukan oleh peneliti terdahulu mengenai pengaruh supervisi akademik yang dilakukan oleh kepala sekolah/ madrasah terhadap kinerja guru.

Penelitian Yesrizal (2012) menyatakan bahwa supervisi akademik memberikan kontribusi yang sangat berarti terhadap keberhasilan pelaksanaan tugas guru, yakni sebesar 41,1 \%, ini berarti apabila semakin tinggi supervisi akademik maka akan semakin tinggi pula keberhasilan pelaksanaan tugas guru di smp negeri kemampuan batang kapas kabupaten Pesisir Selatan. Perbedaan penelitian yang dilakukan dengan penelitian tersebut adalah pelaksanaan supervisi akademik oleh kepala madrasah dalam meningkatkan kinerja guru, selain itu tempat, populasi dan sampel penelitian berbeda. Hijriah (2011) menyatakan pelaksanaan supervisi akademik oleh kepala sekolah di Sekolah Dasar se-Kecamatan Bantul dalam perencanaan mengajar guru termasuk kategori cukup baik (68,8\%), dan evaluasi mengajar guru dalam kategori cukup baik $(59,9 \%)$. Perbedaan penelitian yang dilakukan dengan penelitian tersebut adalah terletak pada pengaruh supervisi akademik oleh kepala madrasah terhadap kinerja guru dalam perencanaan, pelaksanaan dan evaluasi pembelajaran serta tempat, populasi dan sampel yang juga berbeda.

Hasil penelitian tentang "Pengelolaan Supervisi Akademik di SD Negeri 6 Putatsari Grobogan”, sebagai berikut: 1) Pada kegiatan perencanaan supervisi akademik di SD Negeri 6 Putatsari yaitu menyusun jadwal, menyusun perencanaan pembelajaran, dan menyusun daftar guru yang akan disupervisi. 2) Pelaksanaan kegiatan Supervisi Akademik di SD Negeri 6 Putatsari, yaitu supervisor datang ke kelas dengan membawa instrumen yang telah disiapkan untuk mengadakan pengamatan (observasi) pembelajaran sambil mencatat kejadian yang sesuai dengan instrumen. 3) Tindak Lanjut Supervisi Akademik di SD Negeri 6 Putatsari, yaitu kepala sekolah bersama guru mengadakan diskusi pada waktu istirahat di ruang kepala sekolah, di mana guru diberi kesempatan untuk mengungkapkan pendapatnya mengenai proses pembelajaran yang sudah dilaksanakan. Kepala sekolah menunjukkan hasil observasi untuk selanjutnya memberikan kesempatan pada guru untuk mencermati dan menganalisanya 
(Sugiyanti \& Natrimo, 2014). Perbedaan penelitian yang dilakukan dengan penelitian ini adalah terletak pada pengaruh supervisi akademik oleh kepala madrasah terhadap kinerja guru dalam perencanaan, pelaksanaan, tindak lanjut dan dampak supervisi akademik yang dilakukan oleh kepala madrasah serta tempat, populasi dan sampel yang juga berbeda.

Selanjutnya temuan penelitian yang dilakukan oleh Syukri, Cut Zahri Harun, dan Nasir Usman menyatakan bahwa Penyusunan program supervisi akademik kepala sekolah terhadap guru-guru SDN pada gugus I UPTD Dewantara Kabupaten Aceh Utara memuat sasaran/tujuan program, sumber daya yang terlibat, analisis SWOT, dan penyusunan program kerja supervisi akademik yang dirumuskan sesuai dengan kepentingan sekolah dan kebutuhan guru terhadap bimbingan dan layanan didaktik dalam mewujudkan kualitas pembelajaran yang bermutu, Pelaksanaan supervisi akademik terhadap guru-guru SDN pada gugus I UPTD Dewantara Kabupaten Aceh Utara dilakukan dengan cara mempersiapkan sejumlah pertanyaan yang akan ditanyakan kepada guru dengan tehnik kelompok dan individual dan hasil laporannya dikirim langsung oleh kepala sekolah ke Dinas Pendidikan Pemuda dan Olah Raga Kabupaten Aceh Utara, Upaya kepala sekolah dalam pelaksanaan supervisi akademik terhadap peningkatan kinerja guru-guru antara lain melaksanakan rapat guru di sekolah dan mengirimkan guru-guru tersebut untuk mengikuti penataran, mewajibkan seluruh guru untuk membuat RPP yang mencakup standar kompetensi, kompetensi dasar, indikator keberhasilan, dan materi ajar, dan mengumpulkan seluruh instrumen evaluasi yang digunakan oleh guru selanjutnya dijabarkan dalam laporan evaluasi akhir pembelajaran (Syukri, dkk 2015). Perbedaan penelitian yang dilakukan dengan penelitian ini adalah adalah terletak pada pengaruh supervisi akademik oleh kepala madrasah terhadap kinerja guru, tempat, populasi dan sampel yang juga berbeda.

Selanjutnya Susanto menyatakan bahwa terdapat pengaruh positif dan signifikan: (a) kompetensi guru dan kepemimpinan kepala sekolah terhadap motivasi kerja guru SMK di Kabupaten Hulu Sungai Selatan, Kalimantan Selatan, baik secara sendiri-sendiri maupun bersama-sama dengan taraf signifikansi 0,038; 0,045; dan 0,001; (b) kompetensi guru, kepemimpinan kepala sekolah, dan motivasi kerja guru terhadap kinerja guru SMK di Kabupaten Hulu Sungai Selatan, Kalimantan Selatan, baik secara sendiri-sendiri maupun bersamasama, dan secara langsung atau tidak langsung taraf signifikansi 0,036; 0.003; 0,036; 0,000; (0,038 dan 0,036); (0,045 dan 0,036). Perbedaan penelitian yang dilakukan dengan penelitian ini adalah adalah terletak pada pengaruh supervisi akademik oleh kepala madrasah terhadap kinerja guru, tempat, populasi dan sampel yang juga berbeda.

Temuan Penelitian Nasrun juga menyatakan bahwa kepemimpinan kepala SMA Plus Al Azhar yang meliputi dimensi kepribadian, kemampuan 
pengambilan keputusan, kemampuan berkomunikasi, memberi motivasi dan pendelegasian wewenang berada pada kategori sedang. Pengaruh iklim kerja sekolah terhadap kinerja guru ada pada kategori rendah dan kurang cukup memotivasi kinerja guru. Kepemimpinan kepala sekolah dan iklim kerja memberikan pengaruh positif yang signifikan terhadap kinerja guru pada kategori sedang atau kurang cukup meningkatkan kinerja guru terhadap maksimalisasi kinerja dengan stakeholder (Nasrun, 2014). Perbedaan penelitian yang dilakukan dengan penelitian ini adalah adalah terletak pada pengaruh supervisi akademik oleh kepala madrasah terhadap kinerja guru, tempat, populasi dan sampel yang juga berbeda.

\section{Metode Penelitian}

Metode penelitian pada dasarnya merupakan cara ilmiah untuk mendapatkan data dengan tujuan dan kegunaan tertentu. Berdasarkan hal tersebut terdapat tiga kata kunci yang perlu diperhatikan yaitu, cara ilmiah, tujuan, dan kegunaan (Sugiyono, 2014). Metode yang digunakan dalam penelitian ini adalah metode survei dengan pendekatan kuantitatif melalui analisis korelasi dan regresi. Analisis ini akan digunakan dalam menguji pengaruh supervisi akademik yang dilakukan oleh kepala madrasah terhadap kinerja guru di Madrasah Tsanawiyah Tabek Kecamatan Pariangan Kabupaten Tanah Datar.

Penelitian ini dilakukan di Madrasah Tsanawiyah Tabek kecamatan Pariangan Kabupaten Tanah Datar jalan Raya Nagari Tabek. Waktu penelitian ini dilakukan dengan rincian yaitu: a) Observasi awal; b) Seminar proposal; c) Penyiapan insturmen; d) Pengumpulan data, dan e) pengolahan data. Populasi merupakan objek atau subjek yang berada pada suatu wilayah dan memenuhi syarat-syarat tertentu berkaitan dengan masalah penelitian (Riduwan 2005). Berdasarkan observasi awal yang peneliti lakukan pada tanggal 2 sampai 7 Mei 2016, populasi target penelitian ini adalah seluruh guru yang ada di Madrasah Tsanawiyah Tabek yang berjumlah delapan belas orang (18).

\section{Tabel 1. Daftar Nama Guru MTs Tabek Kecamatan Pariangan} Kabupaten Tanah Datar:

\begin{tabular}{cll}
\hline \hline No & Nama Guru & \multicolumn{1}{c}{ Bidang Studi } \\
\hline \hline 1 & Firdaus, Ba & Seni budaya \\
2 & Ira Eliza, S.Pd.I & Bahasa Indonesia \\
3 & Neni Erita, S.Ag & IPS \\
4 & Suhelmi Putra Yandi, S.Ag & Aqidah Akhlak \\
5 & Aida Falta, S.Pd.I & Fiqih \\
6 & Hasna Murni, S. Pd.I & IPS \\
7 & Deni Roswita, S.Pd.I & Tahfiz \\
8 & Amitaza, S.Pd.I & Matemetika \\
\hline
\end{tabular}




\begin{tabular}{cll}
\hline 9 & Dewi Martenret, S.E & Kewarganegaraan \\
10 & Fitria Yunita, S.Pd.I & Matemetika \\
11 & Ifrian Ikramsyah, A.Md & TIK \\
12 & Ummul Hasanah, S.Pd.I & Bahasa Inggris \\
13 & Irfan Wahyudi, S.Pd.I & Bahasa Arab \\
14 & M. Hasnel, S.Ag & Penjaskes \\
15 & Ratna Dewi, S.Pd.I & Bahasa Inggris \\
16 & Yelvira, S.Pd.I & Bahasa Inggris \\
17 & Zulfitri, S.Pd & IPA \\
18 & Fauziah Jurma, S.Pd.I & IPA \\
\hline \hline
\end{tabular}

Berdasarkan populasi di atas maka peneliti mengambil sampel dengan cara sampling jenuh. Sampling jenuh adalah teknik penentuan sampel bila semua anggota populasi digunakan sebagai sampel. Hal ini sering dilakukan bila jumlah populasi relatif kecil, kurang dari 30 orang, atau penelitian yang ingin membuat generalisasi dengan kesalahan yang sangat kecil (Sugiyono, 2013). Berdasarkan kutipan di atas maka penulis menjadikan semua guru yang ada di Madrasah Tsanawiyah Tabek Kecamatan Pariangan Kabupaten Tanah Datar menjadi sampel penelitian yaitu sebanyak 18 orang.

Teknik pengumpulan data menggunakan observasi yaitu melakukan pengamatan secara langsung ke objek peneliti untuk melihat dari dekat kegiatan yang dilakukan. Apabila objek penelitian bersifat perilaku dan tindakan manusia, fenomena alam (kejadian-kejadian yang ada dialam sekitar), maka proses kerja dalam dan penggunaan responden lebih kecil (Riduwan 2005). Dalam penelitian ini observasi bertujuan untuk mengetahui pengaruh supervisi akademik oleh kepala madrasah terhadap kinerja guru di Madrasah Tsanawiyah Tabek kecamatan Pariangan Kabupaten Tanah Datar.

Instumen pengumpulan data adalah alat bantu yang dipilih dan digunakan oleh peneliti dalam kegiatannya mengumpulkan agar kegiatan tersebut menjadi sistematis dan dipermudah olehnya (Sudaryono, 2013). Pada prinsipnya, instrumen penelitian adalah semua alat yang digunakan untuk mengumpulkan, memeriksa, menyelidiki suatu masalah, atau mengumpulkan, mengolah, menganalisis, dan menyajikan data-data secara sistematis serta objektif dengan tujuan memecahkan suatu persolan atau menguji suatu hipotesis (Suryana, 2015).

Penelitian ini menggunakan instrumen berupa angket.angket merupakan tekinik pengumpulan data yang dilakukan dengan cara memberi seperangkat pertanyaan atau pernyataan tertulis kepada responden untuk dijawabnya (Sugiyono, 2014). Dalam penelitian ini peneliti menggunakan angket tertutup. Pada angket tertutup pertanyaaan pokok atau pertanyaan utama, juga ada anak pertanyaan atau sub pertanyaan. Dalam angket tertutup, pertanyaan atau 
pernyataan-pernyataan telah memiliki alternatf jawaban (option) yang tinggal dipilih oleh responden. Dengan kata lain angket berstruktur adalah angket yang disajikan dalam bentuk sedemikian rupa sehingga responden diminta untuk memilih satu jawaban yang sesuai dengan karakteristik dirinya dengan cara memberi tanda silang $(X)$ atau tanda checklist $(\sqrt{ })$ (Sudaryono, 2013).

Pernyataan dibuat dalam bentuk angket dengan menggunakan skala likert 1-5 untuk mendapatkan data yang bersifat interval. Skala likert digunakan untuk mengukur sikap, pendapat dan persepsi seseorang atau sekelompok orang tentang fenomena sosial. Dengan skala likert, maka variabel yang akan diukur dijabarkan menjadi indikator variabel. Kemudian indikator tersebut dijadikan sebagai titik tolak untuk menyusun item-item instrumen yang dapat berupa pernyataan atau pertanyaan (Sugiyono, 2013).

\section{Teknik Analisis Data}

a. Normalitas

Normalitas dihitung untuk mengetahui apakah data yang terkumpul berdistribusi normal. Jika data berdistribusi normal maka hasil penghitungan statistik dapat digeneralisasikan untuk populasi penelitian. Nalisis normalitas data menggunakan rumuas Kmolgorov Smirnov SPSS For windows. Pengambilan keputusan normal atau tidaknya data diputuskan dengan melihat nilai obserbe (observasi) dengan nilai expected (harapan/ideal). Jika nilai Asymp, Sig lebih besar dari 0,05 maka disimpulkan data yang diuji mempunyai distribusi normal. Sebaliknya, jika lebih kecil dari 0,05 maka data mempeunyai distribusi yang tidak normal.

b. Liniearitas

Liniearitas diukur untuk mengetahu liniearitas hubungan antara variabel bebas dengan terikat, yaitu supervisi akademik kepala madrasah $(\mathrm{X})$ dengan kinerja guru $(\mathrm{Y})$. Kriteria yang digunakan adalah apabila harga p pada jalur dev. From Liniearity lebih besar dari harga $\alpha=0,05$ dinyatakan bahwa regresi liniear, dan sebaliknya jika $p$ lebih kecil dari harga $\alpha=0,05$ dinyatakan bahwa regresinya tidak liniear. Teknik yang digunakan dalam hal ini adalah analisis korelasi product moment. Analisis ini akan digunakan dalam menguji besarnya hubungan dan kontribusi variabel $\mathrm{X}$ terhadap variabel $\mathrm{Y}$. Untuk mengetahui derajat hubungan antar variabel supervisi akademik kepala madrasah $(\mathrm{X})$ terhadap kinerja guru $(\mathrm{Y})$ dilakukan penyebaran angket. Untuk mengetahui hubungan antara variabel $\mathrm{X}$ terhadap $\mathrm{Y}$ digunakan teknik korelasi. Analisis korelasi yang digunakan adalah Pearson Product Moment (PPM).

Pengujian lanjutan yaitu uji signifikan yang berfungsi apabila peneliti mencari makna hubungan variabel $\mathrm{X}$ terhadap $\mathrm{Y}$, maka hasil korelasi product moment tersebut di uji signifikan.

c. Uji Hipotesis 
Teknik analisis data untuk menguji hipotesis penelitian ini akan menggunakan persamaan regresi sederhana. Dimana akan dicarai pengaruh yang signifikan antara varaiabel $\mathrm{X}$ dan $\mathrm{Y}$.

\section{Hasil Dan Pembahasan}

Hasilnya adalah signifikansi (sig 2 tailed) sebesar 0,009. Karena signifikan $<0,05$ maka H0 ditolak. Hal ini maka dapat dijelaskan bahwa supervisi akademik kepala madrasah berkolerasi secara signifikan terhadap kinerja guru. Sesuai dengan pengambilan keputusan di atas maka $\mathrm{H}_{0}$ ditolak dan $\mathrm{H}_{\mathrm{a}}$ diterima. Ini berarti terdapat korelasi yang signifikan antara supervisi akademik terhadap kinerja guru di Madrasah Tsanawiyah Tabek, dengan korelasi sebesar 0,594 atau 0,594\%. Karena koefesien mendekati 1 maka dapat disimpulkan bahwa hubungan antara supervisi akademik dengan kinerja guru sedang. Pembahasan dalam penelitian ini dilakukan terhadap temuan/hasil penelitian yang telah dipaparkan di atas yaitu, berdasarkan deskripsi data yang disajikan diperoleh data supervisi akademik kepala madrasah dengan skor tertinggi sebesar 160 dan skor terendah 84. Kemudian data kinerja guru dengan skor tertinggi sebesar 190 dan skor terendah sebesar 132 .

Jika dilihat dari supervisi akademik yang dilakukan oleh kepala madrasah yang dimulai dari perencanaan program supervisi mendapatkan hasil dengan bantuan windows SPSS20 yaitu tentang Perencanaaan Program Supervisi Akademik Kepala Madrasah Tsanawiyah Tabek, hasil penelitian secara deskriptif diketahui nilai minimal adalah 31.00, nilai maksimal adalah 57.00. mean adalah 44.6667, standar deviasi adalah 7.94096. Distribusi frekuensi Perencanaaan Program Supervisi Akademik Kepala Madrasah Tsanawiyah Tabek dalam kategori sangat baik 28\%, baik 33\%, cukup 39\%, kurang 0\% dan sangat kurang $0 \%$. Dengan demikian disimpulkan Bahwa Perencanaaan Program Supervisi Akademik Kepala Madrasah Tsanawiyah Tabek dalam kategori cukup.

Pelaksanaan Program Supervisi Akademik Kepala Madrasah Tsanawiyah Tabek, hasil penelitian secara deskriptif diketahui nilai minimal adalah 30.00, nilai maksimal adalah 49.00 mean adalah 38.7222, standar deviasi adalah 5.64442. Distribusi frekuensi diketahui bahwa Pelaksanaan Program Supervisi Supervisi Akademik Kepala Madrasah Tsanawiyah Tabek dalam kategori sangat baik $0 \%$, baik $44 \%$, cukup $56 \%$, kurang $0 \%$ dan sangat kurang $0 \%$. Dengan demikian disimpulkan Bahwa Pelaksanaan Program Supervisi Akademik Kepala Madrasah Tsanawiyah Tabek dalam kategori cukup.

Tindak Lanjut Program Supervisi Akademik Kepala Madrasah Tsanawiyah Tabek, hasil penelitian secara deskriptif diketahui nilai minimal adalah 17.00, nilai maksimal adalah 41.00 mean adalah 32.1667, standar deviasi adalah 5.60724. Distribusi frekuensi diketahui bahwa Tindak Lanjut Supervisi Akademik Kepala Madrasah Tsanawiyah Tabek dalam kategori sangat baik 17 $\%$, baik $61 \%$, cukup $17 \%$, kurang $5 \%$ dan sangat kurang $0 \%$. Dengan 
demikian disimpulkan Bahwa Tindak Lanjut Supervisi Akademik Kepala Madrasah Tsanawiyah Tabek dalam kategori baik.

Dampak Supervisi Akademik Kepala Madrasah Tsanawiyah Tabek, hasil penelitian secara deskriptif diketahui nilai minimal adalah 5.00, nilai maksimal adalah 15.00 mean adalah 11.4444, standar deviasi adalah 2.52569. Distribusi frekuensi diketahui bahwa Dampak Supervisi Akademik Kepala Madrasah Tsanawiyah Tabek dalam kategori sangat baik $0 \%$, baik $67 \%$, cukup $23 \%$, kurang $5 \%$ dan sangat kurang $5 \%$. Dengan demikian disimpulkan Bahwa Dampak Supervisi Akademik Kepala Madrasah Tsanawiyah Tabek dalam kategori baik.

Kinerja guru di Madrasah Tsanawiyah Tabek kecamatan pariangan kabupaten Tanah Datar yang dilihat dari Penyusunan Rencana Pembelajaran Guru Madrasah Tsanawiyah Tabek, hasil penelitian secara deskriptif diketahui nilai minimal adalah 33.00, nilai maksimal adalah 51.00, mean adalah 44.8333, standar deviasi adalah 4.19032. Distribusi frekuensi diketahui bahwa Penyusunan Rencana Pembelajaran Guru Madrasah Tsanawiyah Tabek dalam kategori sangat baik $17 \%$, baik $78 \%$, cukup $5 \%$, kurang $0 \%$ dan sangat kurang 0\%. Dengan demikian disimpulkan Bahwa Penyusunan Rencana Pembelajaran Guru Madrasah Tsanawiyah Tabek dalam kategori baik.

Pelaksanaan Interaksi Belajar Mengajar Guru Madrasah Tsanawiyah Tabek, hasil penelitian secara deskriptif diketahui nilai minimal adalah 45.00, nilai maksimal adalah 61.00, mean adalah 52.0000, standar deviasi adalah 3.78853. Distribusi frekuensi diketahui bahwa Pelaksanaan Interaksi Belajar Mengajar Guru Madrasah Tsanawiyah Tabek dalam kategori sangat baik $44 \%$, baik $56 \%$, cukup $0 \%$, kurang $0 \%$ dan sangat kurang $0 \%$. Dengan demikian disimpulkan Bahwa Supervisi Akademik Kepala Madrasah Tsanawiyah Tabek dalam kategori sangat baik.

Penilaian Prestasi Belajar Peserta Didik Madrasah Tsanawiyah Tabek, hasil penelitian secara deskriptif diketahui nilai minimal adalah 22.00, nilai maksimal adalah 35.00, mean adalah 30.2778, standar deviasi adalah 4.18408. Distribusi frekuensi diketahui bahwa Penilaian Presatasi Belajar Peserta Didik Madrasah Tsanawiyah Tabek dalam kategori sangat baik $33 \%$, baik $56 \%$, cukup $11 \%$, kurang $0 \%$ dan sangat kurang $0 \%$. Dengan demikian disimpulkan Bahwa Penilaian Presatasi Belajar Peserta Didik Madrasah Tsanawiyah Tabek dalam kategori sangat baik.

Tindak lanjut penilaian prestasi belajar peserta didik di Madrasah Tsanawiyah Tabek, hasil penelitian secara deskriptif diketahui nilai minimal adalah 23.00, nilai maksimal adalah 44.00, mean adalah 36.8889, standar deviasi adalah 5.14369. Distribusi frekuensi diketahui bahwa Tindak Lanjut Penilaian Prestasi Peserta Didik di Madrasah Tsanawiyah Tabek dalam kategori sangat baik $67 \%$, baik $22 \%$, cukup $11 \%$, kurang $0 \%$ dan sangat kurang $0 \%$. Dengan 
demikian disimpulkan Bahwa Supervisi Akademik Kepala Madrasah Tsanawiyah Tabek dalam kategori sangat baik.

Hasil pengujian hipotesis ditemukan bahwa rxy $=0,594$ atau 0,594\%. Dengan taraf signifikan uji $\mathrm{t}$ sebesar 2,950. Dimana kesimpulannya bahwa supervisi akademik kepala madrasah berkolerasi sedang dengan kiinerja mengajar guru.

Adapun besarnya pengaruh yang diberikan oleh supervisi akademikkepala madrasah terhadap kinerja guru adalah 0,594 \% dan 94,06 \% dari faktor lain. Artinya supervisi akademik kepala madrasah memberikan pengaruh terhadap kinerja mengajar guru adalah sebesar 0,594\% dan selebihnya dipengaruhi oleh faktor lain.

Hasil penelitian ini serirama dengan beberapa temuan penelitian bahwa supervisi yang dilakukan kepala sekolah dapat meningkatkan kreatifitas guru dalam segi administrasi dan pelaksanaan pembelajaran di kelas (Yenita, 2015; Renata dkk, 2018; Khasanah dkk, 2019; Andriani dkk, 2018; Apriana dkk, 2019). Kemudian Margaret menyatakan bahwa Terdapat pengaruh positif dan signifikan supervisi akademik kepala sekolah terhadap kinerja guru ekonomi SMA di Kabupaten Sleman. Hal tersebut dapat ditunjukkan dengan nilai t hitung sebesar 2,209, koefisien regresi (b1) sebesar 0,302 dan nilai signifikansi sebesar 0,032. Karena nilaisignifikansi $(\mathrm{p})<0,05$ dan koefisien regresi mempunyai nilai positif, makadapat disimpulkan terdapat pengaruh positif dan signifikan supervisi akademik kepala sekolah terhadap kinerja guru ekonomi SMA di Kabupaten Sleman (Margaret, 2015).

Selanjutnya temuan penelitian ini juga seirama dengan temuan penelitian Nia Kurniati, Johar Permana dan Nani Hartini menyatakan bahwa Pengaruh supervisi akademik kepala sekolah terhadap kinerja mengajar guru di Madrasah Aliyah Negeri (MAN) se- Kabupaten Tasikmalaya mempunyai pengaruh yang rendah dan signifikan. Supervisi akademik kepala sekolah memberikan pengaruh terhadap kinerja mengajar guru sebesar $10,8 \%$ dan sisa sebesar $89,2 \%$ dipengaruhi oleh daktor lain seperti motivasi, kemampuan, faktor pribadi, kedisiplinan, iklim kerja, dan lain-lain (Kurniati, 2014: 10).

Temuan penelitian selanjutnya adalah penelitian yang dilakukan oleh Wildawati, Supomo Kandar, Riswanti Rini.menyatakan bahwa terdapat pengaruh yang positif dan signifikan antara supervisi akademik terhadap kinerja guru, mengandung arti bahwa semakin baik persepsi guru mengenai supervisi akademik maka semakin baik pula kinerjanya (Wildati, 2010: 9).

Selanjutnya penelitian Mubaroh menyatakan bahwa 1) Supervisi akademik kepala sekolah dalam rangka meningkatkan kompetensi pedagogik guru diawali dengan perencanaan program supervisi akademik; 2) Kepala sekolah melaksanakan supervisi akademik dengan beberapa teknik yaitu rapat dewan guru atau secara keseluruhan, kunjungan kelas, observasi kelas, dan 
pembicaraan individu atau supervisi secara individu; 3) Kepala sekolah melakukan evaluasi sebagai tindak lanjut setelah dilakukan supervisi, evaluasi dilakukan kemudian di tindaklanjuti oleh kepala sekolah, 4) Tanggapan guru sangat positif terhadap supervisi yang dilakukan oleh kepala SMP Negeri 1 Punggur, 5) Kompetensi pedagogik yang harus dimiliki oleh guru adalah kemampuan menguasai kurikulum dan menguasai materi pelajaran, penyusunan rencana pelajaran, pelaksanaan pembelajaran, menilai hasil pelajaran (Mubaroh, 2011).

Kemudian teori juga menyatakan bahwa Tingkat keberhasilan kinerja guru, dapat diketahui melalui kegiatan supervisi pendidikan yang dilakukan oleh kepala sekolah dengan menggunakan berbagai teknik supervisi. Kegiatan supervisi yang dilakukan kepala sekolah pada dasrnya merupakan pemberian bantuan atau pertolongan dalam mengembangkan situasi pembelajaran yang lebih baik di madrasah (Supardi, 2013).

Sejalan dengan hal di atas, sebuah temuan penelitian yang bertolak belakang dengan hal di atas yang dilakukan oleh Herlina menyatakan bahwa tidak terdapat pengaruh yang signifikan antara Supervisi Akademik Kepala Sekolah terhadap Professional Guru di SMK Wira Bhakti Payakumbuh Kota Payakumbuh, di mana besar korelasinya yang diperoleh sebesar 4,7\% (Herlina, 2016: 96).

\section{Kesimpulan}

Bahwa terdapat hubungan antara supervisi akademik oleh kepala madrasah terhadap kinerja guru di Madrasah Tsanawiyah Tabek Kecamatan Pariangan Kabupaten Tanah Datar. Kriteria pengujian untuk uji $\mathrm{t}$ adalah jika $\mathrm{t}$ hitung $>\mathrm{t}$ tabel, maka $\mathrm{H} 0$ ditolak dengan didapatkan $\mathrm{t}$ hitung $<\mathrm{t}$ tabel yaitu $(2,950>1,746)$ maka H0 ditolak. Dapat disimpulkan bahwa supervisi akademik berpengaruh signifikan terhadap kinerja guru di Madrsah Tsanawiyah Tabek. Jika supervisi akademik kepala madrasah naik maka kinerja guru juga akan meningkat. Terdapat pengaruh signifikan positif antara kedua variabel dengan perolehan uji hipotesis sebesar 0,009 dan karena hasil tersebut $<0,05$ maka maka H0 ditolak dan nilai koefisien korelasi sebesar 0,594. Dengan perolehan tersebut hubungan antara kedua variabel dikategorikan dalam kategori sedang.

\section{Daftar Pustaka}

Aedi, N. (2014). Pengawasan Pendidikan. Tinjauan Teori dan Praktik. Jakarta: PT Raja Grafindo Persada.

Andang. (2014). Manajemen dan Kepemimpinan Kepala Sekolah Konsep, Strategi,dan Inovasi Menuju Sekolab Efektif. Jakarta: AR-Ruzz Media.

Andriani, S., Kesumawati, N., \& Kristiawan, M. (2018). The Influence of the Transformational Leadership and Work Motivation on Teachers Performance. International Journal of Scientific \& Technology Research, 7(7). 
Apriana, D., Kristiawan, M., \& Wardiah, D. (2019). Headmaster's Competency In Preparing Vocational School Students For Entrepreneurship. International Journal of Scientific \& Technology Research, 8(8).

Arikunto, Suharsimi. (2002). Prosedur Penelitian: Suatu Pendekatan Praktek.Jakarta: Rineka Cipta.

Aslamiah, T. (2011). Hubungan Pelaksanaan Supervisi Akademik Kepala Sekolah Terbadap Kinerja Guru (Study Kasus Di Mtsn Imadun Najab Jakarta. Skripsi FTIK UIN Syarif Hidayatullah Jakarta.

Asmendri. (2012). Teori dan Aplikasi Manajemen Peningkatan Mutu Pendidikan Sekolah dan Madrasah. Batusangkar: STAIN Batusangkar Press.

Asna. (2013). Hubungan Pelaksanaan SupervisI Kepala Sekolah Dan Iklim Organisasi Dengan Kinerja Guru Taman Kanak-Kanak. Kota Padang Panjang. Tesis Pascasarjana Sekolah Tinggi Agama Islam Negri Batusangkar.

Asrizallis. (2015). Kontribusi Etos Kerja Islami dan Pelatihan terhadap Kinerja Guru Madrasah Tsanawiyah Swasta (MTsS) Se- Kota Padang Panjang. AL-Fikrah jurnal manajemen pendidikan.

Dharma, A. (2004). Manajemen Supervisi: Petunjuk Praktis bagi Para Supervisor. Jakarta: PT Raja Grafindo Persada.

Defrisiswardi. (2013). Kontribusi Motivasi Kerja dan Supervisi Akademik Kepala Sekolah terhadap Kompetensi Pedagogik Guru SMA Negeri di Kecamatan Batang Kapas Kabupaten Pesisir Selatan, Padang: Tesis Program Pascasarjana Universitas Negeri Padang.

Departemen Agama RI. (2013). Al-Hikmah, Al-Qur'an dan Terjemahannya, Bandung: CV. Penerbit Diponegoro.

Engkoswara \& Komariah, Aan. (2011). Administrasi Pendidikan. Bandung: Alfabeta CV.

Fathurrochman, I. (2017). Pengembangan Kompetensi Pegawai Aparatur Sipil Negara (ASN) Sekolah Tinggi Agama Islam Negeri (STAIN) Curup Melalui Metode Pendidikan Dan Pelatihan. Manajer Pendidikan, 11(2).

Fitria, R. (2014). Pengaruh Kompetensi Guru dan Iklim Organisasi Sekolah terbadap Kinerja Guru Pendidikan Agam Islam Sekolah Dasar di Kecamatan Gunung Talang Kabupaten Solok, Batusangkar: Tesis Manajemen Pendidikan Islam, Sekolah Tinggi Agama Islam Negeri Batusangkar.

Haslindayeti. (2013). Kontribusi Supervisi Akademik dan Kemampuan Manajemen Kelas Terbadap Pelaksanaan Tugas Guru SMP Negeri Kecamatan IV Jurai Kabupaten Pesisir Selatan, Padang: Tesis Program pascasarjana Universitas Negeri Padang.

Herawati, M. Y. (2015). Pelaksanaan Supervisi Akademik Kepala Sekolah Pada Smp 1 Lhoknga Kecamatan Lhoknga Kabupaten Aceh Besar, (Online), Volume 3, No. 2, Mei 2015. 
Herlina, A. (2016). Pengaruh Supervisi Akademik Kepala Sekolah terhadap Professional Guru di SMK Wira Bhakti Payakumbuh Kota Payakumbuh. Skripsi Fakultas Tarbiyah dan Ilmu Keguruan Jurusan Manajemen Pendidikan Islam Institut Agama Islam Negeri Batusangkar.

Hijriah, R. (2011). Supervisi Akademik oleh Kepala Sekolah di Sekolah Dasar SeKecamatan Bantul, (Online) diakses 3 Juni 2016-06-09.

Irawadi. (2013). Pengaruh Supervisi Kunjungan Kelas Dan Motivasi TerbadapKinerja Guru Sekolah Dasar Negeri Se-Kecamatan Lintan Buo Utara, Batusangkar Tesis Program Pasca Sarjana Sekolah Tinggi Agam Islam Negeri Batusangkar.

Ikhwandra. (2013). P.engaruh Kepemimpinan Kepala Madrasah dan Kerja Tim terhadap Kinerja Guru Pada Madrasah Aliyah Swasta (MAS) Se-Kabupaten Tanah Datar, Batusangkar: Tesis Program Studi Manajemen Pendidikan Islam STAIN Batusangkar.

Jasmani, S. M. (2013). Terobosan Baru dalam Kinerja Peningkatan Kerja Pengawas Sekolah dan Guru. Yogyakarta: Ar-Ruz Media.

Juni P. Donni \& Rismi, S. (2014). Manajemen Supervisi \& Kepemimpinan

Kepala Sekolah. Bandung: CV. Alfabeta.

Khasanah, U., Kristiawan, M., \& Tobari. (2019). The Implementation of Principals' Academic Supervision In Improving Teachers' Professionalism in the State Primary Schools. International Journal of Scientific \& Technology Research, 8(8).

Kristiawan, M., Yuniarsih, Y., \& Fitria, H. (2019). Supervisi Pendidikan. Bandung: Alfabeta

Kurniati, Nia. (2014). Pengarub Supervisi Akademik Kepala Sekolah Terbadap Kinerja Mengajar Guru Di Madrasah Aliyah Negeri (MAN) Se-Kabupaten Tasikmalaya. Jurnal Administrasi Pendidikan, Volume 4, Nomor 1 Desember.

Ma'mur, A. J. (2013). Kiat Melabirkan Madrasab Unggulan. Yogyakarta: Diva Press.

Margaret, S. (2015). Pengaruh Supervisi Akademik Kepala Sekolah dan Lingkungan Kerja terhadap Kinerja Guru Ekonomi Sekolah Menengah Atas (SMA) di Kabupaten Sleman. Skripsi Sarjana, Fakultas Ekonomi Universitas Negeri Yogyakarta.

Mubaroh, M. (2011). Implementasi Supervisi Akademik Kepala Sekolah di SMP Negeri 1 Punggur Kabupaten Lampung Tengah, jurnal mubarok_49@yahoo.com.

Mukhlis. (2013). Kontribusi Supervisi Pembelajaran Terbadap Kinerja Guru SMP Negeri di Kecamatan Sutera Kabupaten Pesisir Selatan. Padang: Tesis Program Pascasarajana Negeri Padang.

Mulyasa. (2004). Menjadi Kepala Sekolah Profesional. Bandung: PT Remaja Rosdakarya.

Mulyasa. (2012). Manajemen \& Kepemimpinan Kepala Sekolah, Jakarta: PT Bumi Aksara. 
Nasrun. (2014). Pengaruh Dan Peran Kepemimpinan Kepala Sekolah Dan Kinerja Guru terhadap Memaksimalisasi Stakeholder di Sma Plus AlAzhar

Pidarta, M. (2009). Supervisi Pendidikan Kontekstual. Jakarta: PT Rineka Cipta.

Prihatin, E. (2011). Teori Administrasi Pendidikan, Bandung: Alfabeta.

Purbasari, M. (2015). Pengaruh Supervisi Akademik terhadap Kinerja Mengajar Guru di Sekolah Dasar, (Online), Jee 4 (1) (2015).

Purwanto, Ngalim. (2010). Administrasi dan Supervisi Pendidikan. Bandung: PT Remaja Rosdakarya.

Renata, R., Wardiah, D., \& Kristiawan, M. (2018). The Influence of Headmaster's Supervision and Achievement Motivation on Effective Teachers. International Journal of Scientific \& Technology Research, 7(4).

Riduwan. (2005). Belajar Mudab Penelitian Untuk Guru, Karyawan Dan Peneliti Pemula. Bandung: Alfabeta.

Rozalinda, Y. (2013). Kontribusi Supervisi Pembelajaran Kepala Sekolah dan Budaya Sekolah terhadap Kompetensi Pedagogik Guru Sma Negeri di Kecamatan XI Tarusan Kabupaten Pesisir Selatan, Padang: Tesis Program Studi Administrai Pendidikan Universitas Negeri Padang.

Rusman. (2011). Manajemen Kurikulum. Jakarta: PT Raja Grafindo Persada.

Safrudin M. E. (2011). Kepemimpinan Pendidikan Transformasional. Jakarta: Diadit Media Press.

Salim, A., \& Agus Z. F. (2010). Madrasah Unggulan Lembag Pendidikan Alternatif di Era Kompetiti. Malang: UIN Maliki Press.

Sarasasti. (2015). Usaha Pengawas Dan Kepala Sekolah Dalam Meningkatkan Kinerja Guru PAI di Madrasah Kota Solok, Batusangkar Tesis Program Pasca Sarjana Sekolah Tinggi Agam Islam Negeri Batusangkar.

Sudaryono. (2013). Penegembangan Instrument Penelitian Pendidikan. Yogyakarta: Graha Ilmu.

Sugiyanti, Sabar Narimo. (2016). Pengelolaan Supervisi Akademik Oleh Kepala Sekolah di SD Negeri 6 Putatsari Grobogan. Jurnal Managemen Pendidikan Vol. 11, No. 2, Januari 2016

Sugiyono. (2013). Metode Penelitian Kuantitatif, Kualitatif dan R\&D. Bandung: CV. Alfabeta.

Sugiyono. (2014). Metode Penelitian Manajemen. Bandung: CV. Alfabeta.

Susanto, H. (2012). faktor-faktor yang mempengarubi kinerja guru sekolah menengah kejuruan. Jurnal Pendidikan Vokasi, Vol 2, Nomor 2, Juni 2012.

Shulhan, M. (2013). Model Kepemimpinan Kepala Madrasah. Yogyakarta, Bandung: CV. Alfabeta.

Supardi. (2013). Kinerja Guru. Jakarta: PT Raja Grafindo Persada.

Suprihatiningrum, J. (2014). Guru Professional Pedoman: Kinerja, Kualifikasi, dan Kompetensi Guru. Yogyakarta: Ar-Ruz Media. 
Suryana, Y. (2015). Metode Penelitian Manajemen Pendidikan: Bandung: Cv. Pustaka Setia.

Syukri. (2015). Pelaksanaan Supervisi Akademik Oleh Kepala Sekolah Untuk Meningkatkan Kinerja Guru Sekolah Dasar Pada Gugus I Uptd Dewantara Aceh Utara. Jurnal Administrasi Pendidikan ISSN 2302-0156 Pascasarjana Universitas Syiah Kuala

Wahyudi. (2012). Kepemimpinan Kepala Sekolah Dalam Organisasi Pemebelajar (Learning Organization). Bandung: CV. Alfabeta.

Wildati. (2014). Pengaruh Supervisi Akademik dan Kepemimpinan Kepala Sekolah terhadap Kinerja Guru Smp Negeri di Kecamatan Sungkai Utara Kabupaten Lampung Utara. Tesis FKIP Universitas Lampung.

Yenderi. (2011). Kontribusi Motivasi Kerja Guru dan Supervisi Kepala Sekolab terbadap Kinerja Guru SD Negeri di Kecamatan Batang Kapas, Padang: Tesis Program Pascasarjana Universitas Negeri Padang.

Yenita, I. (2015). Peningkatan Kreativitas Guru dalam Proses Pembelajaran Melalui Supervisi Akademik di Smp Negeri 2 Pariangan. Jurnal Guru. No 2 Vol 12, Desember.

Yesrizal. (2012). Kontribusi Supervisi oleh Pengawas Sekolah dan Kompetensi Kepribadian Guru terbadap Keberbasilan Pelaksanaan Tugas Guru SMP Negeri di Kecamatan Batang Kapas Kabupaten Pesisir Selatan. Padang: Tesis Program Pascasarjana Universitas Negeri Padang.

Yusmardi. (2011). Kontribusi Kompetensi Manajerial dan Kompetensi Supervisi Kepala Sekolah terhadap Kinerja Guru Sekolah Menengah Kejuruan di Kabupaten Pesisir Selatan, Padang: Tesis Administrasi Pendidikan Universitas Negeri Padang. Zulkifli. (2010). Kontribusi Kreatifitas Guru dan Supervisi Kepala Sekolab terbadap Kinerja Guru SMP Negeri Kecamatan Lubuk Basung Kabupaten Agam, Padang: Tesis Program Pascasarjana Universitas Negeri Padang. 
112 | TADBIR : Jurnal Studi Manajemen Pendidikan, Vol. 3, No. 2, November 2019

This page belongs to the TADBIR : Jurnal Studi Manajemen Pendidikan

TADBIR : Jurnal Studi Manajemen Pendidikan vol. 3 , no. 2, November 2019

IAIN Curup - Bengkulu | p-ISSN 2580-3581; e-ISSN 2580-5037 